\title{
Financial Feasibility Analysis of Red Chili Pepper Seedling at Karanganyar, Poncokusumo, Malang
}

\author{
Dyah Erni Widyastuti ${ }^{1}$, Jabal Tarik Ibrahim ${ }^{2}$, Aris Winaya ${ }^{3}$, Henik Sukorini ${ }^{4}$
}

\begin{abstract}
This research aims to analyse financial feasibility of red chili peppers (Capsicum annum L.) seedling business conducted at Karanganyar, Poncokusumo, Malang. The respondents were farmers who breed red chili peppers and the data collected from March to April 2018. The primary data was collected through interviews based on structure questionnaire to obtain information from selected farmers in the study area. The qualitative study is utilized to analyse the financial feasibility based from Net Present Value (NPV), Internal Rate of Return (IRR), Net Benefit-Cost Ratio (BCR), and Payback Period (PP). This study findings showed a positive NPV (IDR 15403419), IRR is $23.19 \%$, Gross B/C is 1.05 , Nett $\mathrm{B} / \mathrm{C}$ is 1.13 , BCR > 1 (1.05), and PP as 19 months. Despite the costly investment and development, the red chili peppers seedling business is financially feasible.
\end{abstract}

Keywords — Financial Feasibility, Red Chili Pepper Seedling

\section{INTRODUCTION}

$\mathbf{C}$ hili peppers considered as a strategic commodity in agriculture, both red chili peppers (Capsicum annum L.) and cayenne peppers (Capsicum frustescences L.). Despite being a vital commodity, the price of chili peppers remains fluctuated in Indonesia. In certain period, the price of chili peppers increased significantly, but dropped to the cheapest in other time. Due to this yearly price fluctuation, the price of chili papers contributes toward inflation in Indonesia.

In Indonesia, red chili peppers play important roles both in backward linkage as well as forward linkage, notably for food products, condiment, and sauce. Various food products required red chili peppers as basic ingredient, thus resulting in high demand of red chili peppers as well as its seedling seeds.

Previously, the farmers sow all their seeds through conventional methods by themselves only to meet their farming needs, including sowing chili peppers seeds. Due to the high demand, farmers need to create a solution to accelerate the cycle of planting red chili peppers aiming to accommodate its high demand from the market. Consequently, the farmers can promote the red chili peppers seedling in more of industrial ways that are both time- effective and cost-effective compared to sowing chili seeds by themselves ${ }^{4}$.

At the same time, the seedling business opening promising business opportunities for farmers and they are encouraged to invest more in seedling tools, such as greenhouse and other seedling tools. It might be costly to invest for seedling tools, but it is relatively profitable and cost-effective in longer term. In the Province of East Java, there are two red chili peppers farming centre which are Malang and Kediri ${ }^{5}$. The centre in Malang was starting on their red chili peppers seedling business. Thus, this study aims to analyse financial feasibility of red chili peppers (Capsicum annum L.) seedling business conducted at Karanganyar, Poncokusumo, Malang as one of the red chili peppers farming centres in Malang.

\section{MATERIALS AND METHODS}

\section{A. Study Area}

This study carried out in Karanganyar, Poncokusumo, Malang. The sampling of study area was purposively chosen with the consideration as it is one of the centre of red chili peppers seedling business in Malang. In addition, there were a numerous of farmers that owned greenhouses and appropriate seedling tools. The data obtained through a survey, observations, and interviews. The research team used a structured interview guideline to obtain information from selected farmers in the study areas.

\section{B. Financial Analysis}

To evaluate the economic feasibility of investment in red chili peppers seedling tools, the research team counted net present value, internal rate of return, benefit cost ratio, and payback period. The following equations were used to analyse the data ${ }^{6}$.

\section{Net Present Value (NPV)}

The NPV represent the discounted value of the net cash inflows to the business. In this study, a discount factor of $12 \%$ was used to discount the net cash inflows as the opportunity cost of the capital, as follows:

\footnotetext{
Manuscript received June, 22, 2018. This work was supported in part by the Grant of Kementerian Ristek DIKTI

${ }^{1}$ University of Muhammadiyah Malang, Indonesia (corresponding author to provide phone: +6281-233-93080; fax: +62341-460782; e-mail: dyah.erni.w@ gmail.com).

${ }^{2}$ Department of Agribusiness, Faculty of Agriculture and Animal Science, University of Muhammadiyah Malang, (e-mail: jabaltarik2012@gmail.com).

3 Department of Animal Science, Faculty of Agriculture and Animal Science, University of Muhammadiyah Malang, (e-mail: winaya1964@gmail.com).

4 Department of Agrotechnologi, Faculty of Agriculture and Animal Science, University of Muhammadiyah Malang, (e-mail: sukorinihenik@gmail.com
}

$$
\mathrm{NPV}=\sum_{t=1}^{t=n} \frac{B t-C t}{(1+i)^{t}}
$$

Where,

NPV : Net Present Value in period ' $t$ '

Bt : Benefit form chili seedling per year

$\mathrm{Ct}$ : Cost of cultivation per year

i : Discount rate

$\mathrm{t}: \quad: 1,2,3 \ldots \mathrm{n}$, the life plantation across the study area $\mathrm{n} \quad$ : Number of years 
The criteria for NPV as follows:

$\mathrm{NPV}>0$, then it is economically feasible business

$\mathrm{NPV}=0$, then it is BEP

$\mathrm{NPV}<0$, then it is not economically feasible business

\section{Internal Rate of Return (IRR)}

The rate at which the NPV of project is equal to zero is internal rate of return (IRR) to the business. The net cash inflows were discounted to determine the present worth by the following interpolation technique. Derivation of the IRR is analogous to solve ' $\mathrm{i}$ ' in the equation given as follows:

$$
\mathrm{IRR}=\sum_{t=1}^{t=n} \frac{B t-C t}{(1+i)^{t}}=0
$$

Based on the equation above, the correlation between IRR and Social Opportunity Cost of Capital (SOCC) as follows:

IRR > SOCC, then it is feasible to run the business

$\mathrm{IRR}=\mathrm{SOCC}$, then it is BEP

IRR $<$ SOCC, then it is not feasible to run the business

\section{Benefit Cost Ration (BCR)}

The BCR of an investment is a ratio of the discounted value of all cash inflows to the discounted value of all cash outflows during the life of the business and counted as follows:

$$
\mathrm{BCR}=\frac{\sum_{t=1}^{t=n} \frac{B t}{(1+i)^{t}}}{\sum_{t=1}^{t=n} \frac{C t}{(1+i)^{t}}}
$$

Based on the equation above, the criteria for BCR are:

$\mathrm{BCR}>1$, then it is a feasible business

$\mathrm{BCR}=1$, then it is $\mathrm{BEP}$

$\mathrm{BCR}<1$, then it is not a feasible business

\section{Payback Period (PP)}

$\mathrm{PP}$ is the time in which the initial cash outflows of an investment is expected to be recovered from the cash inflows generated by the investment. It is one of the simplest investment appraisal techniques. The formula to calculate the payback period of a business depends on whether the cashflow per period from the business in even or uneven. In the case that it is even, the formula to calculate payback period is ${ }^{7,8}$ as follows:

$$
\text { Payback Period }=\frac{\text { Initial Investment }}{\text { Cash Inflow per Period }} x 1 \text { year }
$$

If the business get a shorter PP compared to its maximum payback period, then the investment is considered as feasible. However, this method neglects the value of money over time and the cash inflows after the payback. Despite the drawbacks of this method, it is still used to support for better methods and to encourage better research findings.

\section{RESULTS AND DISCUSSION}

\section{Investment}

Investment is every cost that need to be paid by the seedling farmers which not affected by the price of the products. The investment that need to be paid to start a red chili peppers seedling business are showed in Table 1 .

\begin{tabular}{|c|c|c|}
\hline No & Description & Investment (IDR) \\
\hline 1 & Land $(1,400 \mathrm{~m} 2)$ & $420,000,000$ \\
\hline 2 & Build greenhouses (5 units) & $55,000,000$ \\
\hline \multirow[t]{2}{*}{3} & Seedling tools & $5,965,000$ \\
\hline & Total & $480,875,000$ \\
\hline
\end{tabular}

\section{TABLE 1.}

INVESTMENT

\section{Cost of Production}

The cost of production of a business divided into two, which are fixed or capital cost and variable cost. Fixed cost is the cost that used to develop the farm, including the irrigation systems, roads, stores, farm machineries, and rain protective structure for the chili seedling. While the variable costs including all expenses that varied according the scale of the production, such as wages for workers, planting materials, fertilizers, pesticides and utilities ${ }^{9}$.

\section{Operational and Maintenance Cost (OM)}

The operational and maintenance cost is all expenses to operate the production system for it to run smoothly, including wages of workers, overhead cost for electricity and water. Wages of men as a worker is IDR 50,000 per day. The workers must water the seeds, cultivate the soil and put the fertilizers, harvest the corps, and clean the weeds. The wages of women as a worker is IDR 7,500 per 1,000 polybags. The female workers must put the soil and the fertilizers into the polybag. While other workers who put the seeds into the polybag will be paid IDR 2,400 per 1,000 polybags. On average, the overhead cost for electricity and water is IDR 50,000 per month, and for the rent for the land is IDR $1,250,000$ per year. Thus, the total OM cost for the two years red chili peppers seedling business is IDR 61,532,250 per month.

\section{Financial Feasibility Analysis}

The indicators of financial feasibility analysis carried out based on cash inflows and outflows. The cash inflows include revenue, while the cash outflows include investment and operational cost. Table 2. showed the financial feasibility analysis based on NVP, IRR, BCR, and PP. 
TABLE 2

Financial Feasibility and Payback Periode Analysis of Chilli SEEDLING CULTIVATION

\begin{tabular}{lc}
\hline \hline \multicolumn{1}{c}{ Viability Indicators } & Value \\
\hline Net Present Value (NPV) @ 9\% & IDR 15,403,419 \\
\hline Gross B/C & 1.05 \\
\hline Nett B/C & 1.13 \\
Internal Rate of Return (IRR) & $23.19 \%$ \\
Average Benefit (Ab) & IDR 5,875,334 \\
Payback Period (in month) (PP) & 19 \\
\hline
\end{tabular}

Based on the Nett $\mathrm{B} / \mathrm{C}$ ratio, the farmers may able to earn 1.13 per 1 invested in red chili peppers seedling business. Furthermore, the greenhouse system can be used for numerous time of red chili peppers production, while the conventional methods only feasible for 3-5 times production. The intensive greenhouse system implementation in red chili peppers seedling business offers more benefits for the farmers compared to the conventional methods. On average, the production of red chili peppers seedling is between $60,000-$ 200,000 polybags that can be harvest after $30-36$ days. The investment and the development in red chili peppers seedling business may be costly, but the intensive greenhouse system provides a short-term capital return in around 19 months. Thus, the high number of production may compensate the high investment and development cost for the greenhouse system.

\section{Viability Analysis}

Viability analysis is used to measure the technology utility and implementation in the business based on cashflows. Correspondently with the previous findings on financial feasibility analysis, the high number of production is not only depending on the farming environment, but also the quality of the seeds and plantation management ${ }^{10}$. Improving the usage of technologies and farming machineries among farmers will significantly affect the productivity of the farm as well as the revenues ${ }^{11}$. Innovations and updated technologies is a pivotal factor to improve the farming outputs and the products competitiveness $^{12}$ supported with the relevant information of which compatible technologies, operational cost, and the rate of capital return ${ }^{13}$ to help farmers boost the productivity and revenues.

The viability analysis on utilising the technologies for the red chili peppers seedling process showed better quality of seeds and more profitable in a longer term for farmers. At the same time, this effort may reduce red chili peppers import while open wider business opportunity to explore products that used chili peppers-based as its ingredients. The technology utility ensures the sustainability of red chili peppers supplies for the products in the forward linkage.

\section{CONCLUSION}

The red chili peppers seedling business using the intensive greenhouse system showed improvement in productivity and revenues for farmers compared to the conventional methods. The high investment and development cost in the beginning of the process will be compensate with the doubled productivity and revenues. On the other hand, the implementation of greenhouse system and irrigation system may prevent other farming technologies among farmers. Despite the disadvantages, the financial feasibility analysis showed that the red chili peppers seedling business showed better competitiveness and feasible to be adopted by red chili peppers farmers in other areas. Furthermore, the intensive greenhouse system applied the principle of sustainable farming and more environmentally friendly compared to the conventional methods.

\section{REFERENCES}

[1] TPID P. RELEASE NOTE INFLASI FEBRUARI 2017. 2017.

[2] (TPI) TP dan PI. Analisis Inflasi Maret 2016. 2016.

[3] Bank Indonesia. Skema Pembiayaan Pertanian dengan Pendekatan Konsep Rantai Nilai (Value Chain Financing). Bank Indonesia; 2015. 246 p.

[4] Widisatriani GAYU, Widyantara IW, Angreni IGAAL. Manajemen Rantai Pasok Benih Cabai Rawit ( Kasus di Yayasan Idep , Desa Batuan Kaler , Kecamatan. 2015;4(4):289-97.

[5] Pusdatin. Outlook Cabai: Komoditas Pertanian Sub Sektor Hortikultura tahun 2015. Pusat Data dan Informasi Pertanian, Sekretariat Jenderal Kementerian Pertanian; 2016.

[6] Guleria A, Tiwari P, Sharma R. Cost of Cultivation and Economic Feasibility of Grafted Harar ( Terminalia chebula ) In Himachal Pradesh. 2017;5(2):1005-11.

[7] Yaseer Suhaimi Mohd, Adzemi Mat Arshad, Nur Farah Hani Muhamad and NJS. Potential and Viability of Chilli Cultivation Using Fertigation Technology in Malaysia. Int J Innov Appl Stud. 2016;17(4 Sep. 2016):4 Sep. 2016.

[8] Suhaimi MY, Mohammad AM, Hani MNF. Potential and viability analysis for ginger cultivation using fertigation technology in Malaysia. Int J Innov Appl Sci [Internet]. 2014;9(1):421-7. Available from: http://www.ijias.issr-journals.org/abstract.php?article=ijias-14251-28

[9] Pradesh A. AN ECONOMIC ANALYSIS OF CHILLIES PRODUCTION IN GUNTUR DISTRICT OF Scenario in Andhra Pradesh. 2015;5(9):43-9.

[10] Triani HDP. Studi Kelayakan Bisnis. Yogyakarta: Graha Ilmu; 2009.

[11] Harun R, Suhaimee S, Zaffrie M, Amin M, Sulaiman NH Benchmarking and prospecting of technological practices in rice production. Econ Technol Manag Rev. 2015;10b:77-88.

[12] Karneta R. Analisis Kelayakan Usahatani Cabe Merah Keriting ( Capsicum annum L ) dan Kacang Panjang ( Vigna sinensis L ) Secara Rotasi Menggunakan Teknologi Olah Limbah pada Lahan Sub Optimal Feasibility Analysis Farming Curly Red Chilli ( Capsicum annum L ) and Lon. 2015;

[13] Mohammed B, Abdulsalam Z, Ahmed B. Profitability in Chilli Pepper Production in Kaduna State, Nigeria. Br J Appl Sci Technol [Internet] 2016;12(3):1-9. Available from:

http://sciencedomain.org/abstract/11656 